These reviews are available open access under a CC BY 4.0 license as part of Berghahn Open Anthro, a subscribe-to-open model for APC-free open access made possible by the journal's subscribers.

\title{
EXHIBITION REVIEWS
}

\section{Hogarth: Place and Progress, Sir John Soane's Museum, London, 9 October 2019 - 5 January 2020.}

An invitation to explore Hogarth: Place and Progress at Sir John Soane's Museum after normal opening hours "accompanied with a Sipsmith Gin \& Tonic" was intriguing-not least because the exhibition included Gin Lane (1751), one of the best-known depictions of alcohol abuse ever published. It may be unique for a government-funded museum to promote itself so counterintuitively. But, since so much about the exhibition defied expectation, it proved to be a strikingly apposite marketing strategy.

It is hard to know what to make of Hogarth. The Dictionary of National Biography properly describes him as a painter and engraver (Bindman 2009), but that is the least of it. Despite a considerable body of portraits and history paintings in the grand manner, Hogarth is probably most thought of as the "grandfather of satire" (Rowson 2007), if not "the father of the modern cartoon" (Mount 2014). Traditionally described as an iconoclast at odds with the British fine art world of his time (Solkin 1993), his work appears far less radical when viewed in the context of contemporaneous print and literary cultures (Hallett 1998; Uglow 1997). Hogarth's subject matter has been described variously-as antiauthoritarian, John Bullish, xenophobic, modern, and Masonic (Bell 2015; Brooks and Curzi 2014; Hilton 1997). The tercentenary of his birth prompted even more interpretations based on his illustrations of luxury, women, slaves, and sexual desire (Fort and Rosenthal 2001). Given the scale of Hogarth studies, it is not surprising that some readings of his works are disputed (Molineux 2005) and others criticized as simply implausible (Dorment 1993; Paulson and Dorment 1993). But, whatever the tags attached to his work, Hogarth has consistently been regarded as a moralist, not least since his widow commissioned John Trusler's Hogarth Moralized (1768).

By focusing on the artist's Modern Moral Subjects, the exhibition and its related publication (jointly referred to as "the project") affiliated themselves with that tradition. Rather than pigeonholing Hogarth as a radical social critic who championed the lower classes, the project highlighted his condemnation of moral behaviors across society. It argued that the types of conduct depicted in his narrative series were influenced by the physical and social circumstances in which his protagonists found themselves.

Explorations of the relationship between physical places and moral practices emerged as an academic field in the 1970s. The discipline of moral geography proposes that geographical context is crucial to understanding distinctive ethical judgments and perceptions of difference, otherness, inequality, and social justice. "Moralities are, in short, constructed through geographically articulated social interaction," according to Roger Lee and David Smith (2004: 7).

The project's investigation of Hogarth's moral geography principally concentrated on London: the West End, inhabited by aristocrats and aldermen; the City, occupied by merchants and those 
engaged in its financial and credit services; and the disreputable areas between, which were characterized by brothels, inns, taverns, beer houses, liquor shops, and their habitués. Two series set outside London are also included-The Humours of an Election, inspired by the excessive spending and corruption of the notorious 1754 Oxfordshire election, and the incomplete The Happy Marriage (after 1745). These, however, appear somewhat peripheral to the overall thrust of the project.

Previous writers have associated the allegorical narratives of Hogarth's protagonists with their "literal journeys through the capital" (Porter 2003: 17), pinpointing many of the locations used (O'Connell 2003: 57, 63-65). Pragmatically, the project mapped the precise locations shown in the series. Conceptually, it described how those places, their institutions, and their associated virtues and vices signified Hogarth's protagonists' relative moral and social standing at particular times and shaped the opportunities open to them. By charting the consequences of his subjects' social mobility upward and downward, Hogarth quantified their incremental progress toward demotion, promotion, death, and deliverance. Thus, the Rake's progress is not only affected by his acquisition and, subsequent, loss of money, but where those events occurred-in his merchant father's house in the City; the spacious, aristocratic house he acquired in the West End; and the illicit Rose Tavern, Drury Lane. At the climax of his narrative, the Rake is arrested for debt on his way to be presented at the Court of St. James. His options close down from here as his trajectory takes him on to Fleet Prison and Bedlam.

In arguing for the significance of Hogarth's moral geography, the exhibition brought together-reportedly, for the first time-the artist's ten extant painted and engraved seriesincluding those in the Sir John Soane's Museum's collection. The earliest piece shown was $A$ Harlot's Progress (1732) and the last, the Tail Piece, or The Bathos (1764), was made shortly before Hogarth's death to complete his collected engravings. While not part of a series, it was crucial to the project, since it represents the nadir of the artist's pessimism about society's moral decay and his alienation from it.

Hogarth: Place and Progress was installed throughout the museum. With the exception of the first two rooms, containing A Harlot's Progress and A Rake's Progress, Marriage-A-la-Mode, and The Happy Marriage, it fitted around the permanent display of the museum's collection and personal effects.

But, even allowing for the maximum 85 people in the building ${ }^{1}$ and timed admissions (not due to COVID-19), the exhibition spaces were packed-especially at the start, where the two Progresses were displayed. The 14 paintings of A Rake's Progress were hung on substantial freestanding screens, inspired by those shown in an 1884 illustration in The Graphic. But while that showed a single visitor closely scrutinizing the series, extending the same privilege to one or two people in 2019 was unworkable: the installation generated a bottleneck with visitors queuing and straining to look. Low ambient light levels and surface reflections made it hard to examine the paintings.

Visitors do not want to be jostled at the beginning of an exhibition: it prompts them to speed up, pay less attention, and lose patience. The half-hourly after-hours tour (costing $£ 25$ in contrast to the normally free admission) was not much of an improvement: the pressure on the space and time available was palpable as other groups came into view.

Although Hogarth intended his engravings to be read at different levels (indeed, the exhibition included simple woodcut versions of The Four Stages of Cruelty [1751]), the project must have been intended to enhance the appreciation of his work. But even so simple an ambition constituted a serious challenge for a public museum committed to maintain, or maximize, its visit numbers while allowing its audiences to critically engage with its displays (Cuno 2004). Since the meaning of the Modern Moral Subjects largely resides in the minutiae of their iconography, their 
depictions of controversial contemporary figures and inscriptions, the success of the exhibition depended on how well its audience was able to read those images and appreciate the project's hypothesis.

According to the standard orthodoxy, the longer people look at pictures the more they discover about them, if not about themselves. T. J. Clark (2006) went as far as recording the process of coming to terms with two Poussins that he engaged with over a six-month period. Others, including James Elkins (2004), have remarked on people's lack of engagement with the art that they encounter in galleries. While it is unclear whether the convention of visiting exhibitions for social reasons (Morris Hargreaves McIntyre. n.d.) encourages or discourages people to look, the annual Slow Art Day is deliberately intended to encourage people to look more. ${ }^{2}$ It can, however, be argued, that persistent belief in the authority of the purely visual may devalue the artist's specific intentions.

Looking only gets you so far with Hogarth. Even if, as the museum's data implies, those visiting Hogarth: Place and Progress are likely to have been well-educated and highly motivated (DCMS 2012, 2020), they are unlikely to have been familiar with mid-eighteenth-century London history and politics. The majority would have relied on the information panels, captions, and brochure for basic information about the narratives, the locations, the incidents represented, and the iconography.

It is unclear whether the catalogue would have helped many of the exhibition's lay audience, or even whether it was intended for them as opposed to the contributors' academic peers. Judith Dobrzynski (2010) argues that as few as 2 percent of exhibition visitors usually buy the catalogue. Those for popular shows and those featuring familiar artists tend to sell badly: regular gallery-goers regard themselves as sufficiently acquainted with the artist to warrant not buying it, and occasional visitors are insufficiently committed to doing so.

The largest section of the publication is devoted to the catalogue-reproductions, descriptions, and interpretations of the works included. The remainder consists of scholarly essays by Bruce Boucher, the museum's director, and Hogarth scholars David Bindman (as guest-curator), Frédéric Ogée, and Jacqueline Riding.

Bindman's contributions are those most closely identified with Hogarth: Place and Progress's central theme. Having introduced that, he was also responsible for mapping Hogarth's London, validating and adding to sites previously identified by Elizabeth Einberg (2016) and Ronald Paulson (1989). His essay tackled Hogarth's misconceived reputation as "The People's Artist": rather than targeting particular individuals or social classes, he was motivated by people's general immorality and unerring instinct for self-destruction.

Although Riding focuses on the rewards of virtue apparent in the rural idyll of The Happy Marriage, conceived as a positive counterpoint to the metropolitan misery of Marriage-A-laMode, the other contributions are less committed to the themes of place and progress. Boucher concentrates on the museum's collection of Hogarths, but resists the temptation to explore any connections between A Rake's Progress and the fate of Soane's own sons. (This is, however, explicitly addressed at John Soane's country retreat, Pitzhanger Manor.) Ogée reflects on the construction of Hogarth's pictorial sequences, not least as "narratives of Newtonian cases and effects" (2019: 41).

Despite, or perhaps because of, its academic ambitions, the project neglected Hogarth's current appeal-beyond the museum's exploitation of the revival of gin drinking. But, by definition, its revelation that moral geography so profoundly informs the meaning of Hogarth's narratives necessarily refers to how we make sense of places and communities today. And, by confining itself within the boundaries of art history, the project limited its potential: a social or public 
historian might have added considerable value by explaining how, and why, moral values differed in the times, places, social worlds, and cultures in which Hogarth placed his protagonists.

Visitors to Sir John Soane's Museum would have tacitly recognized many of Hogarth's themes: social aspiration, predatory activity, abuse of parliamentary privilege, and anti-European sentiment. They would have identified many of the issues addressed in the Modern Moral Subjects-conflicting social attitudes, ${ }^{3}$ unethical consumption, racism, sexism, inequality, and antisocial and pathological behaviours. But, they may well have been uncomfortable with the images themselves.

In these woke times, the exhibition served as a stark reminder of how our expectations have been shaped, precisely because Hogarth confounds them so effectively. We are used to the polemics of much contemporary art, and to works that reflect belonging and identity politics that represent specific groups, political factions, and different ethnicities and sexualities. ${ }^{4}$ Hogarth's narrative series are the diametric opposite: his satire targets all sectors of society, and his images stand out as detached, brutal, and uncomfortable.

Sara Selwood, London

\section{NOTES}

1. See: Alan Allkan Interviews: Bruce Boucher, 3 December 2017: https://www.alainelkanninterviews. com/bruce-boucher/ (accessed 24 September 2020).

2. See: Slow Art Day website: https://www.slowartday.com/ (accessed 24 September 2020).

3. See, for example, three 2019 British social attitudes surveys: Policy Institute (n.d.); Curtice et al. (2019); and BBC Media Centre (2019).

4. This line of thinking is indebted to Packer (2020).

\section{REFERENCES}

BBC Media Centre. 2019. "What Does the UK Think Is Right and Wrong? The BBC Reveals a Snapshot of Morality in 2019." BBC Media Centre, 21 November. https://www.bbc.co.uk/mediacentre/ latestnews/2019/year-of-beliefs-morality-ethics-survey-2019.

Bell, Jeremy J. 2015. “The Freemason's Harlot: William Hogarth's Harlot's Progress in a Masonic Light.” British Art Journal 16 (2): 42-49. https://www.jstor.org/stable/24913964.

Bindman, David. 2009. "Hogarth, William (1697-1764)." Oxford Dictionary of National Biography. https://www.oxforddnb.com/view/10.1093/ref:odnb/9780198614128.001.0001/odnb -9780198614128-e-13464 (accessed 1 March 2020).

Brooks, Carolina, and Valter Curzi. 2014. Hogarth Reynolds Turner: British Painting and the Rise of Modernity. Rome: Fondazione Roma Museo.

Clark, T. J. 2006. The Sight of Death: An Experiment in Art Writing. New Haven, CT: Yale University Press.

Cuno, James. 2004. Whose Muse? Art Museums and the Public Trust. Princeton, NJ: Princeton University Press.

Curtice, John, Elizabeth Clery, Jane Perry, Miranda Phillips, and Nilufer Rahim, eds. 2019. British Social Attitudes: The 36th Report. London: The National Centre for Social Research. https://www.bsa .natcen.ac.uk/media/39363/bsa_36.pdf (accessed 1 March 2020). 
Department of Culture Media and Sport (DCMS). 2012. "Performance Indicators 2011/12 Data Spreadsheet.” DCMS, 24 October. https://www.gov.uk/government/statistics/annual-performance -indicators-2011-12.

Department of Culture Media and Sport (DCMS). 2020. "Sponsored Museums and Galleries Annual Performance Indicators 2018/19.” DCMS, 24 October. https://www.gov.uk/government/statistics/ sponsored-museums-and-galleries-annual-performance-indicators-201819.

Dobrzynski, Judith D. 2010. "Cataloguing the Changes: Museums Start to Shift from Traditional Exhibition Catalogues to Print-on-Demand and Online Versions." The Art Newspaper. September. http:// www.judithdobrzynski.com/7969/cataloguing-the-changes.

Dorment, Richard. 1993. “The Genius of Gin Lane.” New York Review of Books, 27 May. https://www .nybooks.com/articles/1993/05/27/the-genius-of-gin-lane/.

Einberg, Elizabeth. 2016. William Hogarth: A Complete Catalogue of the Paintings. New Haven, CT: Yale University Press.

Elkins, James. 2004. Pictures and Tears. London: Routledge.

Fort, Bernadette, and Angela Rosenthal, eds. 2001. The Other Hogarth: Aesthetics of Difference. Princeton, NJ: Princeton University Press.

Hallett, Mark. 1998. "Hogarthomania and Print Culture." Art History 21: 499-451. doi:10.1111/1467-8365.00121.

Hilton, Tim. 1997. "Just a Load of Old Bull." The Independent, 16 February. https://www.independent. co.uk/arts-entertainment/just-a-load-of-john-bull-1278934.html.

Lee, Roger, and David M. Smith. 2004. "Introduction: Geographies of Morality and Moralities of Geography." In Geographies and Moralities: International Perspectives on Development, Justice and Place, ed. Roger Lee and David M. Smith, 1-12. New York: John Wiley and Sons.

Molineux, Catherine. 2005. "Hogarth's Fashionable Slaves: Moral Corruption in Eighteenth-Century London.” ELH 2 (2): 495-520. doi:10.2307/30029984.

Morris Hargreaves McIntyre. n.d. London Temporary Exhibitions Report. Manchester: Morris Hargreaves McIntyre. https://mhminsight.com/articles/london-temporary-exhibitions-report-3681 (accessed 1 March 2020).

Mount, Harry. 2014. "Hogarth: The Father of the Modern Cartoon." The Telegraph. 1 November. https:// www.telegraph.co.uk/comment/personal-view/11202643/Hogarth-the-father-of-the-modern -cartoon.html.

O'Connell, Sheila. 2003. London 1753. London: British Museum.

Ogée, Frédéric. 2019. The Pleasure of Progress: Hogarth and the Pictorial Sequence. In Hogarth: Place and Progress In Hogarth: Place and Progress, 35-41. London: Sir John Soane's Museum.

Packer, George. 2020. “The Enemies of Writing.” The Atlantic, 23 January. https://www.theatlantic.com/ ideas/archive/2020/01/packer-hitchens/605365/.

Paulson, Ronald. 1989. Hogarth's Graphic Works, 3rd rev. ed. London: The Print Room.

Paulson, Ronald, and Richard Dorment.1993. "An Exchange on Hogarth." New York Review of Books, 27 May. https://www.nybooks.com/articles/1993/08/12/an-exchange-on-hogarth/.

Policy Institute. n.d. How British Moral Attitudes Have Changed in the Last 30 Years. London: Policy Institute, King's College London. https://www.kcl.ac.uk/policy-institute/assets/British-moral-attitudes. pdf (accessed 1 March 2020).

Porter, Roy. 2003. “The Wonderful Extent and Variety of London.” In London 1753, ed. Sheila O'Connell, 9-17. London: British Museum.

Rowson, Martin. 2007. “The Grandfather of Satire: William Hogarth.” Tate etc. 9. https://www.tate.org.uk/ tate-etc/issue-9-spring-2007/grandfather-satire.

Solkin, David H. 1993. Painting for Money: The Visual Arts and the Public Sphere in Eighteenth-Century England. New Haven, CT: Yale University Press.

Uglow, Jenny. 1997. Hogarth: A Life and a World. London: Faber and Faber. 


\section{Place, Nations, Generations, Beings: 200 Years of Indigenous North American Art, Yale University Art Gallery, New Haven, Connecticut, 1 November 2019-28 February 2021}

"Indigenous North American art is an enduring presence at Yale University." Opening the Yale University Art Gallery's (YUAG) Place, Nations, Generations, Beings: 200 Years of Indigenous North American Art, this powerful statement sets the tone. The temporary exhibition and accompanying catalogue (McCleary et al. 2019) is Yale's first attempt at reconciling its role within the history of salvage museum anthropology. The exhibition's student-led curatorial team accomplishes this by explicitly naming the mechanisms of settler colonialism and by foregrounding community voices in the display of Indigenous art. Thematically organized, the exhibition works against the remnants of cabinets of curiosity and natural history institutions-it is not the chronology or geography that matters, but the distinctive epistemological themes and community narratives that tie the exhibition together.

In many ways, Yale is late to these conversations. Museum anthropological praxis has been radically shifting for the past several decades, and Yale has largely been silent. This exhibition is a hopeful attempt at not only recalibrating the Gallery's ethos but also Yale's thinking on broader contemporary sociopolitical issues. Curated by then-Yale undergraduates Katherine Nova McCleary (Little Shell Chippewa-Cree) and Leah Tamar Shrestinian, with Joseph Zordan (Bad River Ojibwe), the exhibition is the institution's first of its kind. Though rooted in decolonizing museological methodologies, this exhibition, situated within an institution that stems from and perpetuates colonial violence, should not be seen as a project of decolonization. Here, we should revisit what Eve Tuck (Unangax) and K. Wayne Yang tell us about what is "unsettling" about decolonization in their pivotal "Decolonization Is Not a Metaphor" article: it "brings about the repatriation of Indigenous land and life; it is not a metaphor for other things we want to do to improve our societies" (2012: 1). In conversation, Shrestinian noted that the exhibition-as it does not actively facilitate the return of Indigenous objects and land-is instead "inspired by decolonial work." ${ }^{\prime}$ By collaborating with Indigenous students and faculty at Yale, foregrounding Native voices and epistemologies, and revealing Yale's complicity in settler colonial methods of collecting, the exhibition's co-curators effectively indigenized the Gallery space.

As named, Place, Nations, Generations, Beings is broken into four sections, each with a distinctive goal. Visitors can enter the exhibition from either "Place" or "Beings", though the "Place" entrance is much more central within YUAG, and the floorplan is largely open, allowing visitors to move through the space as they wish. As the curators chose the objects before the four organizing themes were developed, Shrestinian noted that they:

wanted the objects to speak and drive the work. The show is fundamentally about relationships. For example, while [the theme of] place kept coming up, it wasn't just [about] place, it was the relationships between objects, artists, and places-the basis of all four themes are the relationships.

In these planning stages, the process would have been significantly strengthened with community input. According to McCleary and Shrestinian, they were aware of this structural problem, but given their positions as student curators, the timeline they were working on, and the lack of resources available to them from the institution, community collaboration at these early stages was unattainable. In response to this situation, McCleary, Shrestinian, and Zordan created an informal network of collaborators, including Native students and faculty at Yale and external 


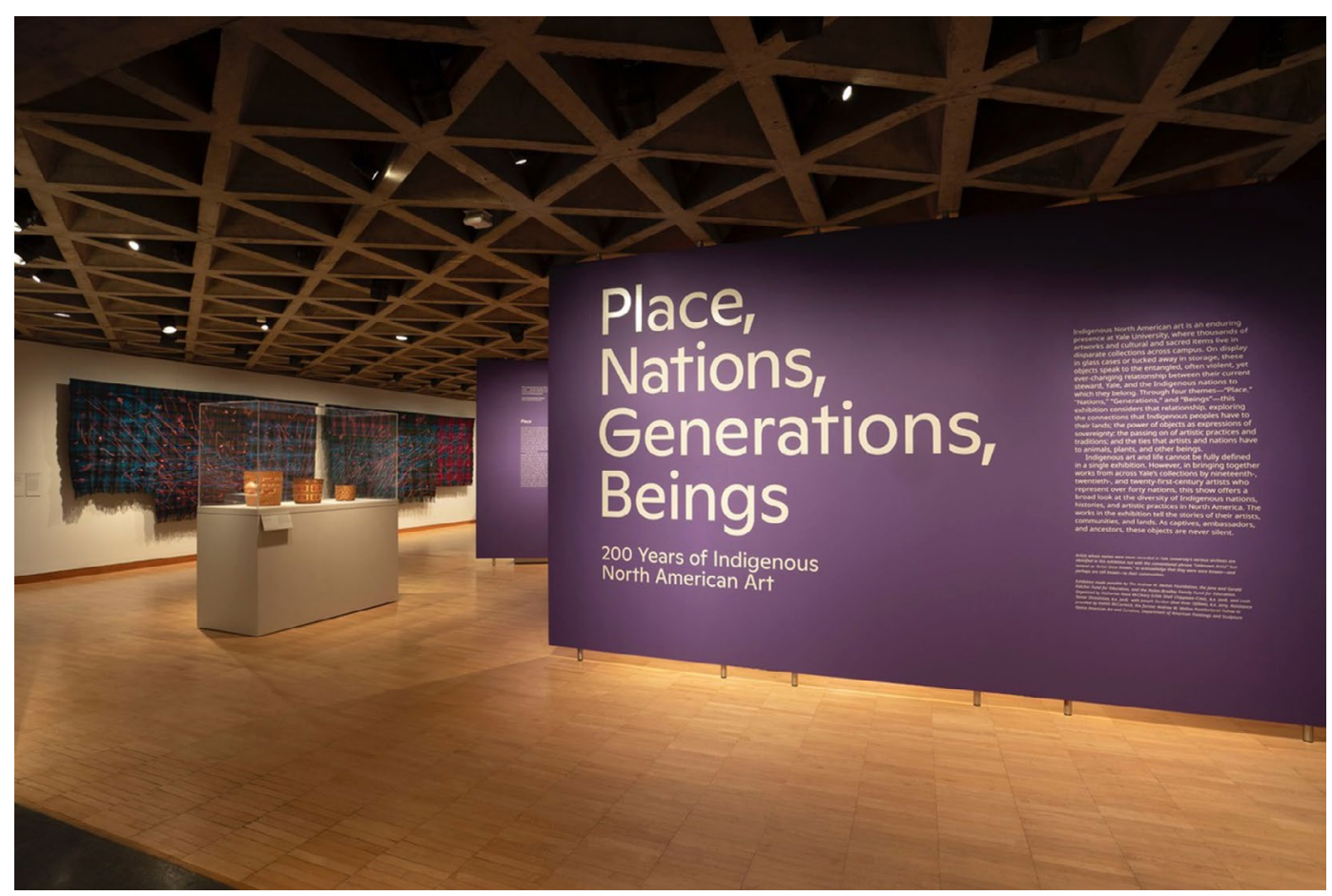

Figure 1. View of the exhibition Place, Nations, Generations, Beings: 200 Years of Indigenous North American Art, Yale University Art Gallery. Photo is courtesy of Jessica Smolinski.

scholars. Here, working with Indigenous students was particularly important for McCleary: "It showed Yale how much Indigenous knowledge is indeed at Yale; not just within gallery spaces, faculty, or staff, but within the students themselves." This is one of the most significant impacts of the project-it demonstrated the ways in which so-called anthropological or art historical "expertise" often fails communities, and asked Yale to rethink their positionality in relationship to the community-based knowledge(s) that their students hold.

Indeed, at the start of the exhibition's development, the curatorial team was also tasked with building the foundational infrastructure for Yale to engage with Native people and communities. After several years of development, in April 2018, the Native American and Indigenous Arts Advisory Council crystalized, allowing Indigenous artists, historians, and community members to visit Yale and work with the exhibition's content. In a discussion with McCleary, I was told that the output from those conversations demonstrated to Yale how essential community advisory councils are to this work, as her reflections on the process demonstrate:

In summary, if we were to do this again, with more support and resources, we would go about the entire process differently. And though we sort of were able to make up for that in many ways, the project would've benefited from [having] those ongoing relationships.

The exhibition's opening text panel reads, in part: “On display in glass cases or tucked away in storage, these objects speak to the entangled, often violent, yet ever-changing relationship between their current steward, Yale, and the Indigenous nations to which they belong." Evoking 
Michael Ames's glass box, the exhibition centers the histories of anthropology and collecting before any objects are presented to the visitor (Ames 1992). Not only discussed at the exhibition's entry, Yale's history is omnipresent throughout the gallery. Māori scholar Linda Tuhiwai Smith (Ngāti Awa, Ngāti Porou) calls this "remembering" an Indigenous project; though painful, honoring historical trauma is necessary for healing (Tuhiwai Smith 2012). Following this line of thought in its opening section, "Place," 200 Years stresses the fact that land is central to the colonial project (Wolfe 1999, 2006). "Place" evokes not only the dispossession of homelands, but makes the intertangled mechanisms of settler control clear:

Settler policies and genocidal acts, such as mass relocations, massacres, and imprisonment, forced Indigenous peoples from their homes and attempted to sever their relationships with their lands and waterways. Though the objects in this exhibition may reside in Yale's collections, they remain tied to their homelands and nations: they belong to those who wove, carved, and shaped them; they belong to those who used and cared for them; they belong, still, to the thriving nations from which they come (from the Wall text; emphasis added)

Visitors are provoked to think deeply about the specific legacies of settler colonialism. For Ho-Chunk historian Amy Lonetree, this telling of the "full story of the Native American holocaust provides a testament not to Native victimhood but to Native skill, adaptability, courage, [and] tenacity ... that make our survival a reality against all odds" (2012: 6-7). And here, an adjacent Mohegan hickory basket serves as a poignant reminder that Yale was built upon Algonquian homelands. The basket highlights the inextricable connections between artist, homeland, collector, and institution, while the other items exhibited in this section, also rooted in place, tell stories of innovation, tradition, and adaptation in the face of relocation and genocide. The next section, "Nations," foregrounds Indigenous sovereignty in relation to creative production and community. Here, Will Wilson’s (Diné) Critical Indigenous Photographic Exchange Project links colonial methods of documentation to contemporary notions of visual sovereignty, in which he reinscribes agency to the subjects, who are photographed on their own terms. And drawings from Indigenous artists imprisoned at Fort Marion in Saint Augustine, Florida, tell intimate stories of displacement from both homeland and community. The right to self-representation remains a constant theme throughout "Nations":

[A]rtists resisted assimilation and helped assert sovereignty through self-representation, affirming family and community bonds, maintaining artistic techniques, and sustaining cultural practices. Through their materials, designs, and processes, these artists have played a vital role in the continuation of Indigenous sovereignty. (McCleary et al. 2019: 81)

"Nations" celebrates and makes visible artistic exchange between communities, creative responses to colonial forces, and the sociopolitical complexities of Native governmental relations.

By continuing to foreground the socioeconomic pressures of settler colonialism, the third section, "Generations," examines intergenerational knowledge in relation to authenticity, community aesthetics, and innovation: "Despite direct violence and pressure from settler states to assimilate, artists ensure that community practices and knowledge endure" (McCleary et al. 2019: 123). This affirmation is exemplified by Sam Jacobs's (Tlingit) miniature totem pole-an ancestral art form transformed for the tourist market-and by works from The Studio School of the Santa Fe Indian School, where Pueblo artists applied pottery designs to works on paper, further shifting their ancestral aesthetics into new contexts. This section deeply interrogates settler ideas of "traditional" arts and aesthetics, and demonstrates the creative brilliance of Native artists in the face of genocide. 


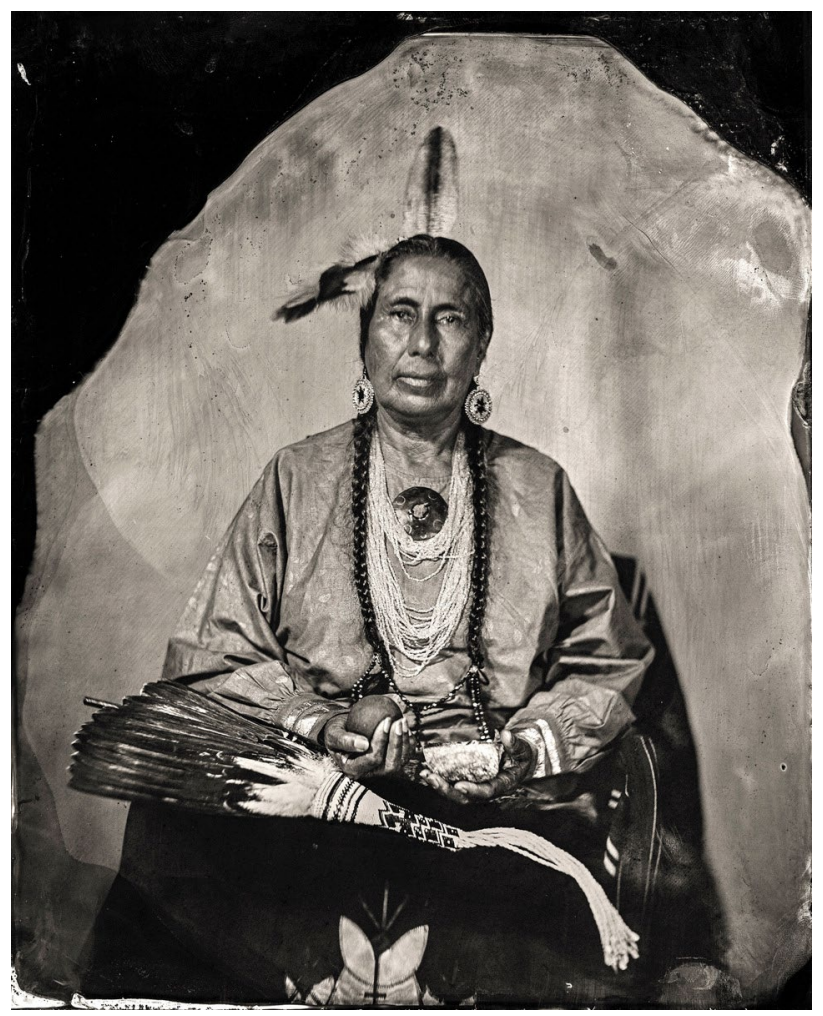

Figure 2. Will Wilson (Diné [Navajo]), Casey Camp Horinek, Citizen of Ponca Tribe of Oklahoma, "Zhutni," Tribal Councilwoman, Leader of Scalp Dance Society, Sundancer, Delegate to UN Permanent Forum on Indigenous Issues, Matriarch of Wonderful Family (Grandmother, Companion, Mother, Sister), Defender of Mother Earth, 2016. Archival pigment print from wet-plate collodion scan. Beinecke Rare Book and Manuscript Library, Yale Collection of Western Americana, WA Photos Folio 184. (C) Will Wilson, Artist. Courtesy of Beinecke Rare Book and Manuscript Library.

Finally, the smallest section of 200 Years examines Indigenous people's relationships with nonhuman "Beings." Careful to avoid colonial tropes of spirituality, the exhibition faces these settler stereotypes head-on:

There are many popular misconceptions about Indigenous religions and spiritualities. Non-Indigenous people often overlook the diversity of beliefs not only among nations but also within them. Settlers may also mythologize, homogenize, or fetishize Indigenous peoples' relationships to beings. (from the Wall text)

As such, the reciprocal relationships between makers, communities, objects, and beings are explained through power. This section primarily exhibits artistic representations of beings, but also includes items intended for community use, such as Richard Hunt's (Kwakwaka àwakw) Sea Monster Mask. Commissioned by the Yale Peabody Museum of Natural History, the mask draws attention to the multiplicities of meaning that can be embedded in physical renderings of beings: the item is representative of a particular event in a specific Kwakwaka'wakw narrative; it is visually stunning, artistically innovative, and, perhaps most importantly, it is meant to be danced. As the exhibition's final section, visitors are likely to have learned about the role museums play 


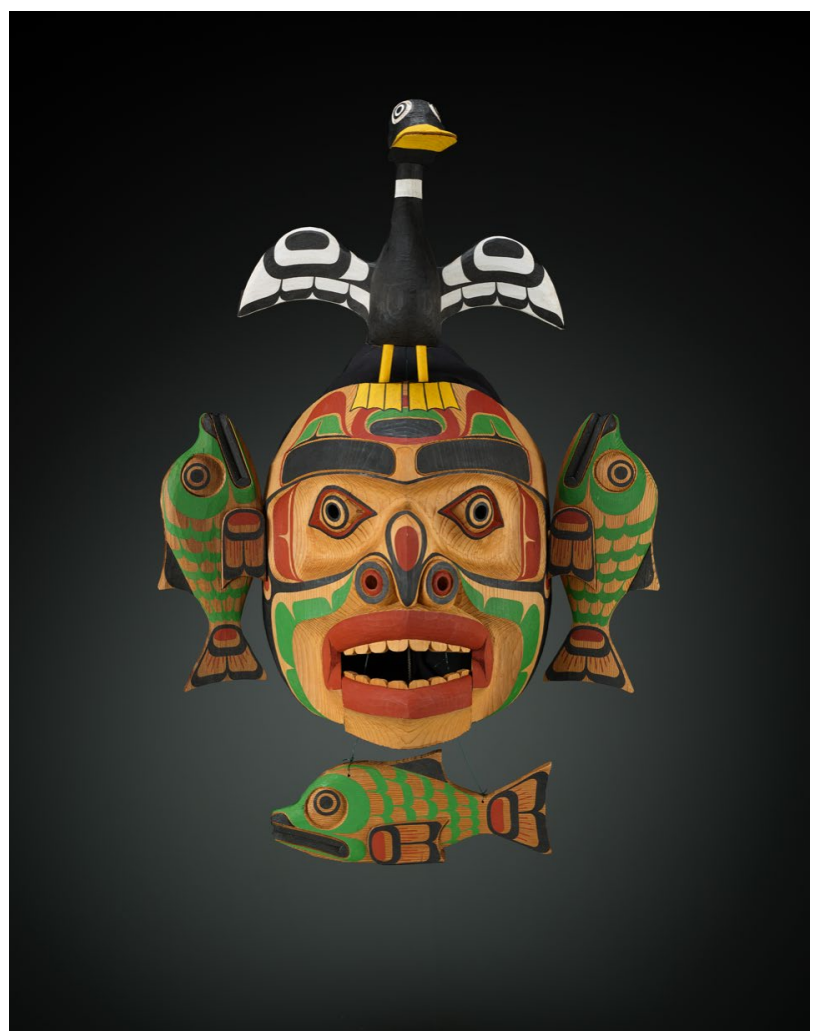

Figure 3. Richard Hunt (Kwakwạka’wakw), Sea Monster Mask, 1999. Red cedar with pigment and metal. Yale Peabody Museum of Natural History, inv. no. ypm ant.256928.

(C) Richard Hunt. Courtesy of Yale Peabody Museum of Natural History

in the colonial project and thereby question why these beings are housed at Yale, a key curatorial strategy and educational tactic.

The exhibition brings together objects from across Yale's campus. The Beinecke Rare Book and Manuscript Library, the Peabody Museum of Natural History, and YUAG have long served as disparate, fragmented repositories for Indigenous belongings. By temporally and physically reorienting these items within YUAG, the colonial obsession with systematic classification is made clear, though the objects are concurrently reclassified as "art," a contentious statement in its own right. Grappling with this, McCleary and Shrestinian aimed to exhibit Indigenous items as "art" with the goal of showcasing the "excellence of creation that isn't encapsulated in words [such as] craftspeople.” And to further distill these tensions, they used the exhibition's design to aesthetically and ideologically make clear to the visitor that they were entering a space that argues for a "different" definition of art more reflective of Indigenous communities' own artistic conceptions.

Beyond curatorial strategy, the consciousness of 200 Years of Indigenous North American Art extends into design. Deep purple walls evoke wampum, a nod to the Haudenosaunee people on whose lands Yale stands, while a Diné chief's blanket is displayed outside of a vitrine and on a human form, asking the viewer for whom the blanket was made. Evocative quotes from contemporary Indigenous artists and scholars frame the objects and line the walls. According to Shrestinian, the design was a "celebration of the vibrancy of the art," and McCleary viewed 
the design as a way to center Indigenous voices and visitors by asking what colors her own community would want to see in the gallery space.

Here, perhaps the exhibition's most valuable contribution is the use of "Artist Once Known" on object labels. ${ }^{2}$ Replacing the more widely used "Artist Unknown," "Artist Once Known" makes the violence of the museum and the archive blatant. What knowledges and narratives were once known? To whom? This poignant curatorial mechanism reinscribes power to the maker and to the community - and away from the institution. In discussing this choice, the curators noted that YUAG staff were "a little resistant" to the new descriptor, thinking that non-Native visitors would largely be confused. Despite this, according to Shrestinian, they used it in their speaking and writing about the exhibit, spending significant time explaining the ways in which the terminology "humanizes the artists . . giving them their personhood back." Eventually, the Gallery "begrudgingly agreed."

Successful in several aspects, Place, Nations, Generations, Beings does leave the viewer with several lingering questions, the most pressing of which is how this exhibition has, or has not, influenced Yale's relationship(s) with Indigenous people. And though there are many positive aspects to student-led curatorial team, it does leave significant questions in its wake. Why has Yale not invested in a full-time Curator of Native American Art? Why and how are these burdens continuing to fall on young Indigenous people, whose labor is so often underrecognized and underpaid? In an interview with Artnet News, McCleary explained: "We realized that if we didn't take this opportunity, the show was likely not going to happen" (Cascone 2020).

Indigenous undergraduates compose a growing percentage of Yale's student body, but as an institution whose alumni include John Calhoun, the founder of the Bureau of Indian Affairs, Yale has significant work to do. ${ }^{3}$ Here, it is important to think about how 200 Years, and the Gallery itself, mobilized through student activism and engagement, can serve as an agent for sociopolitical change. The exhibition's key questions are these: How can university museums work as catalysts for institutional change? What types of power do exhibitions exert? And how can this power be wielded for decolonization?

According to McCleary and Shrestinian, at the beginning of the project, talking about Native art was an "entirely new conversation" at YUAG. While they believe the exhibition provided Yale staff with a framework and vocabulary to engage with Indigenous art, and created an "intellectual space" for these conversations to take place, they are hesitant to argue that the Gallery can serve as a catalyst for university-wide shifts. ${ }^{4}$

The exhibition, though far from revolutionary, marks an important first step toward reworking the temporal and spatial boundaries of the university, and toward the possibility of a more just and equitable future for Indigenous students, staff, and faculty at Yale. In a discussion of the narratives surrounding American history, Yale Professor of History and advisor to the exhibition, Ned Blackhawk (Western Shoshone), tells us that it "does little good to add Indians into a flawed mosaic of American history without first reworking the temporal and spatial boundaries of the field" (2006: 5). The same can be said for museums, universities, and their collections and exhibitions. Overall, the exhibition indigenizes the gallery space by telling a compelling story about Native arts and epistemologies from Indigenous perspectives in the context of an elite collecting institution. Resistance, innovation, and survivance (Vizenor 2008) in the face of colonial power is acknowledged and celebrated, while Yale's central role in perpetuating settler violence is concurrently investigated. A successful exhibition curated by a team of undergraduates, Place, Nations, Generations, Beings marks an important moment in student and Native-led scholarship at Yale.

\section{Lillia McEnaney}

Independent Scholar, Santa Fe, New Mexico 


\section{Acknowledgments}

I would like to acknowledge the lands on which this review was written: the occupied, ancestral homelands of the Tewa Pueblos of O'gha Po'oge, also known as Santa Fe, New Mexico. As a non-Native settler and visitor to this place, I wish to acknowledge the Native people-past, present, and future-who walk on these lands, and demonstrate a commitment to dismantling the ongoing legacies of settler colonialism.

\section{NOTES}

1. The quotes from the co-curators are from discussions we had on 27 July 2019.

2. The terminology of "artist once known" was first used at the Art Gallery of Ontario (AGO) in exhibitions curated by Wanda Nanibush (Beausoleil First Nation).

3. According to the University's Native American Cultural Center (2020), there are "currently over 100 students at Yale College who identify as American Indian, Alaska Native, and Native Hawaiian," and in the 2019 admissions cycle, Yale admitted 2,304 students (Yale News 2020) -indicating that approximately 4 percent of the student body identifies as Indigenous.

4. Recently, the Advisory Council formed for the exhibition made a number of recommendations - primarily about creating staff positions - to the Bieneicke, Art Gallery, and Peabody, though they are still waiting to see movement from Yale on these issues, according to McCleary and Shrestinian. As we have seen elsewhere, tangible institutional change is often rooted in Indigenous student activism, and for McCleary "it is going to take a lot of time and continued effort by Native students at Yale to push them forward, ... though I am excited about the new levels of awareness and support among more Gallery staff." Shrestinian also noted that Yale-largely due to its endowment-is uniquely positioned to be a leading institution in the field: "They are positioned to do this work; it's just now them deciding to do it."

\section{REFERENCES}

Ames, Michael. 1992. Cannibal Tours and Glass Boxes: The Anthropology of Museums. Vancouver: University of British Columbia Press.

Blackhawk, Ned. 2006. Violence over the Land: Indians and Empires in the Early American West. Cambridge, MA: Harvard University Press.

Cascone, Sarah. 2020. "Musfaeums Have Stumbled When It Comes to Curating Native American Art: These Students Are Modeling a New Way Forward." Artnet News, 24 January. https://news.artnet .com/exhibitions/a-new-way-to-curate-indigenous-art-1754667.

Lonetree, Amy. 2012. Decolonizing Museums: Representing Native America in National and Tribal Museums. Chapel Hill: University of North Carolina Press.

McCleary, Katherine Nova, and Leah Tamar Shrestinian, with Joseph Zordan. 2019. Place, Nations, Generations, Beings: 200 Years of Indigenous North American Art. New Haven, CT: Yale University Press.

Tuck, Eve, and K. Wayne Yang. 2012. "Decolonization Is Not a Metaphor." Decolonization: Indigeneity, Education, Society 1 (1): 1-40. https://jps.library.utoronto.ca/index.php/des/article/view/18630.

Tuhiwai Smith, Linda. 2012. Decolonizing Methodologies: Research and Indigenous Peoples. New York: Zed Books.

Vizenor, Gerald, ed. 2008. Survivance: Narratives of Native Presence. Lincoln: University of Nebraska Press. 
Yale University Native American Cultural Center. 2020. “Undergraduate Admissions.” Yale University Native American Cultural Center, 31 July. https://nacc.yalecollege.yale.edu/admissions-recruitment/ undergraduate-admissions.

Yale News. 2020. "Yale College Admits 2,304 Students; Fourth Year of Expanded Class Size." Yale News, 26 March. https://news.yale.edu/2020/03/26/yale-college-admits-2304-students-fourth-year -expanded-class-size.

Wolfe, Patrick. 1999. Settler Colonialism and the Transformation of Anthropology: The Politics and Poetics of an Ethnographic Event. New York: Cassell Press.

Wolfe, Patrick. 2006. "Settler Colonialism and the Elimination of the Native." Journal of Genocide Research 8 (4): 387-409. doi:10.1080/14623520601056240. 